\title{
David Oliver: Constant structural reorganisation won't improve or transform healthcare
}

\author{
David Oliver consultant in geriatrics and acute general medicine
}

Berkshire

\begin{abstract}
NHS leaders and politicians seem to have an endless obsession with organisational restructuring. The King's Fund has produced narrated animations of the NHS "organogram," ${ }^{2}$ showing the bewilderingly complex accountabilities created by the 2012 Health and Social Care $\mathrm{Act}^{3}$ and subsequent new organisational forms and workarounds, such as integrated care systems emerging from NHS England's Five Year Forward View. ${ }^{4}$
\end{abstract}

In May 2018 a report presented at a meeting of the boards of NHS Improvement and NHS England set out why and how the two bodies should work more closely. ${ }^{5}$ In the same week the health policy analyst Nick Timmins, in The World's Biggest Quango ${ }^{6}$ reflected on how differently NHS England now operates from the then health secretary Andrew Lansley's original vision when it was established in 2012.

Lansley moved public health to local government, created Health Education England and Public Health England, scrapped the 10 strategic health authorities that coordinated and oversaw care across natural geographical regions, and disbanded primary care trusts, replacing them with clinical commissioning groups (CCGs).

This plunged the system into entropy and uncertainty for several years, with most new posts being filled by existing NHS staff who had to reapply for roles. ${ }^{17}$ And Lansley's populist rhetoric on "reducing bureaucracy" ${ }^{8}$ wasn't realised, as the rapid change and added complexity ultimately led to a continuing need for good NHS managers and a reliance on consultancy, ${ }^{79}$ which is shown to add little to NHS efficiency in a recent London School of Economics report. ${ }^{10}$

Yet, around the 2010 general election, NHS performance was already improving steadily each year, the funding and workforce deficit was less severe than now, and public satisfaction was high. ${ }^{11}$ There was no need for this political vanity project of reorganisation for its own sake.

Lansley also stated that, in his new world, the health secretary should be far less involved in NHS operational issues and less accountable for its performance, which were for NHS England to resolve. ${ }^{38}$ Yet his successor, Jeremy Hunt, is intensely involved in NHS operational matters and finance, whatever the 2012 act set out to achieve. ${ }^{6}$

I'd bet big money that most frontline NHS staff, let alone the public, will have little understanding of the different roles of the national arm's length bodies and where the Department of Health and ministers' roles start and stop, as well as the new local structures that have undergone little consultation. The obsession with new structures can leave even seasoned policy watchers baffled.

There was no need for this political vanity project of reorganisation for its own sake

In essence, the proposals ${ }^{5}$ for NHS England and NHS Improvement's civil partnership intend to recreate some of the pre-Lansley simplicity and single lines of accountability and the regional groupings of CCGs, vaguely akin to but smaller than the strategic health authorities his bill scrapped.

We need to end our fixation with restructuring. On reviewing the evidence, respected health policy analysts and think tanks have concluded that structural reorganisation, new form hierarchies, or mergers are not the way to deliver service improvement, transformation, or sustainability. ${ }^{12-15}$ They rarely deliver the benefits imagined, especially in a complex adaptive system such as the NHS, where all change brings unintended and unforeseen consequences. ${ }^{16}$

It is the behaviours, values, and actions of local teams of clinicians and managers, in a conducive environment of adequate workforce numbers and resources, that matter most in delivering improvement or subverting change. ${ }^{12}{ }^{17}$ Yet we still don't learn.

Competing interests: See www.bmj.com/about-bmj/freelance-contributors/david-
oliver.
Provenance and peer review: Commissioned; not externally peer reviewed.

King's Fund. An alternative guide to the new NHS in England. 27 June 2013. https://www. youtube.com/watch?v=8CSp6HsQVtw.

2 King's Fund. How is the NHS structured? 19 Oct 2017. https://www.kingsfund.org.uk/ audio-video/how-new-nhs-structured. 
3 Department of Health and Social Care. Health and Social Care Act 2012: fact sheets. 15 June 2012. https://www.gov.uk/government/publications/health-and-social-care-act-2012fact-sheets.

4 NHS England. NHS five year forward view. https://www.england.nhs.uk/five-year-forwardview/.

5 NHS England. NHS Improvement. Meeting in common of the boards of NHS England and NHS Improvement. 24 May 2018. https://www.england.nhs.uk/publication/nhs-englandand-nhs-improvement-board-meetings-in-common-agenda-and-papers-24-may-2018/.

6 Timmins N. "The world's biggest quango": the first five years of NHS England. King's Fund. 24 May 2018. https://www.kingsfund.org.uk/publications/worlds-biggest-quangonhs-england.

7 Institute for Government. Never again? The story of the Health and Social Care Act 2012. 12 July 2012. https://www.instituteforgovernment.org.uk/publications/never-again.

8 Department of Health and Social Care. Liberating the NHS white paper. 12 July 2010. https://www.gov.uk/government/publications/liberating-the-nhs-white-paper.

9 Oliver D. Stop wasting taxpayers' money on management consultancy for the NHS. BMJ 2014;349:g7243. 10.1136/bmj.g7243 25491703

10 Kirkpatrick I, Sturdy A, Veronesi G. London School of Economics and Political Science. Using management consultancy brings inefficiency to the NHS. 10 March 2018. http // blogs.Ise.ac.uk/politicsandpolicy/using-management-consultancy-brings-inefficiency-tothe-nhs/.
11 Maybin J, Thorlby R. A high-performing NHS? A review of progress 1997-2010. King's Fund. 11 April 2010. https://www.kingsfund.org.uk/publications/high-performing-nhs.

12 Ham C. Reforming the NHS from within: beyond hierarchy, inspection and markets. King's Fund. 11 June 2014. https://www.kingsfund.org.uk/publications/reforming-nhs-within.

13 Lewis R. Size versus quality? Examining hospital mergers. Nuffield Trust. 16 Jan 2013. https://www.nuffieldtrust.org.uk/news-item/size-versus-quality-examining-hospital-mergers.

14 Goddard M, Ferguson B. Mergers in the NHS: made in Heaven or marriages of convenience? Nuffield Occasional Papers-Health Economics series paper no 1. Nuffield Trust. 1997. https://www.nuffieldtrust.org.uk/files/2017-01/mergers-in-the-nhs-web-final. pdf.

15 Malby B, Fischer M. Effective Organisational Forms in the NHS. University of Leeds. April 2012. http://www.cihm.leeds.ac.uk/wp-content/uploads/2014/05/Hierarchies-SystemsNetworks-April-2012.pdf.

16 Kuziemsky C. Decision-making in healthcare as a complex adaptive system. Healthc Manage Forum 2015;8. http://journals.sagepub.com/doi/abs/10.1177/0840470415614842? journalCode=hmfa. 26656389

17 Bohmer RMJ. The hard work of health care transformation. NEJM Catalyst 7 Nov 2016. https://catalyst.nejm.org/hard-work-health-care-transformation/.

Published by the BMJ Publishing Group Limited. For permission to use (where not already granted under a licence) please go to http://group.bmj.com/group/rights-licensing/ permissions 